\title{
Menstruation: Social Construction and Experience
}

\author{
Swastika Dutta and Jyoti Prasad Saikia \\ Department of Sociology, Dibrugarh University, Dibrugarh, India
}

\begin{abstract}
Menstruation is a basic natural physiological process that all young girls go through to a certain period but in our society, it is considered an important milestone covered with many social beliefs and practices. This particular paper is completely based on an empirical field study conducted during my research work while keeping in the front objective of how society reconstructed this menstruation process. Women have been seen as central characters for this paper and their own experience and from narrative have been kept on the front while arriving at an understanding whole social construction on "menstruation". I analyzed the data by using some thematic decomposition, such as "Comparison with Blooming Flower: A Mark of Fertility", "A Social Taboo", "Curse: Socio-Cultural Perception towards Menstruation", "Status of pollution" and try to portray social reality.
\end{abstract}

\section{KEY WORDS: MENSTRUATION, SOCIETY, SOCIAL CONSTRUCTION, WOMEN.}

\section{INTRODUCTION}

In a western developed society, the main concern regarding menstruation was "hygiene and sanitation", wherein eastern society depicts the opposite picture and associated with social taboo, impurity, dirt, etc. There are many cultural repetitions of blood, ranging from family and kinship to violence and war, menstrual blood is almost always positioned negatively (Bramwell, 2001) Menstruation is a transformation period for a girl from childhood period to adulthood period. Leela Dube in her work, clearly states that the first step of change that occurs in a girl's life is marked by puberty which is also considered as her first move towards the construction of femininity and her feminine quality. now the question emerges "what means to be a girl or a women? "Lies in our whole socialization process, which informs her about changing body and persona. In one account one of the participants said,

"God created females with this natural process of menstruation. so, as a female and we are bounded to have menstruation on monthly basis for a certain period. This is nature's rules therefore we should live by these rules

Biosc Biotech Res Comm P-ISSN: 0974-6455 E-ISSN: 2321-4007

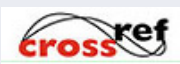

Identifiers and Pagination

Year: 2021 Vol: 14 No (9) Special Issue

Pages: 20-23

This is an open access article under Creative

Commons License Attribn 4.0 Intl (CC-BY). DOI: $h t t p: / / d x . d o i . o r g / 10.21786 / b b r c / 14.9 .5$ along with existing taboo" In India menstruation being seen as a social and cultural entity and our Society has created existing taboo and social practices restricting women to do their normal work and bound them for suffering. If we looked at it from a scientific lens this socio-cultural taboos and practices nothing but all are man-made and socially culturally constructed. Due to a lack of knowledge and awareness young girls and women have started accepting things as they are being told by society. All-female is born and brought up to accept it wholeheartedly and pass it on to next generation to maintain social and cultural belief system. The attitude of our society hasn't changed since a long time ago though the generation has changed. Rather it has been passed to the next generation where girls cannot talk about menstruation with other family members because it a considered a topic of taboo. The culture and religious beliefs regarding menstruation play an oppressive role in a female's life. It's like society has built a tradition to which every female has to follow their whole life without even thinking of the actual relevance or reason behind those beliefs (Spanier), 1978).

Objective: The main aim of the present article is to address social construction on menstruation, how a menstruating woman is treated and viewed by society, and to know how socially this normal physiological process is being shaped by our society in various form of social taboos, rigid practices, belief, how menstruation is being categorized as a mark for womanhood, and how on one side menstruation is considered as "status of pollution" and on the other hand Goddess Ma Kamakhya is being
Article Information

Received: $12^{\text {th }}$ Apr 2021

ccepted after revision: $19^{\text {th }}$ June 2021 
worshipped all around in India during her menstrual days.

\section{METHODOLOGY}

This article is a part of my research work. Participants were young girls and women between the age group of thirteen and sixty years old. Interviews and focus group discussions were conducted during the time of fieldwork with two different ethnic background communities i.e Nepali and Assamese people reside in komolsapori area with the help of an open-ended interview schedule. Purposively I have chosen this field while keeping in front my objective of research work.

Comparison With Blooming Flower: A Mark of Fertility: People of komolsapori area strongly believe that menstruation is directly linked with the fertility of women. According to them, the process of menstruation creates waste or polluted blood and also prepares a women's body for conceiving a child it is a sign of fertility that is unique to a woman. It is a sign of the capability of women to reproduce a new life. Considering the fact of the fertility of womanhood, Menstruation is being compared with blooming flowers. During the fieldwork, Aroti saikia (a women) housewife (42), described menstruation by comparing menstruation with a flower said, "Once a girl starts her puberty, there is flower get implant naturally, and this kind of flower blossoms during the whole month and at the end when the flower dies naturally and came out in a form of blood from the vagina, which we knew as menstruation. Menstrual blood is considered as bad blood, which should be flowing out every month in other to have healthy fertility life. And ironically when a woman gets pregnant, this flower blossoms to bear fruits. Here in this context fruit symbolize a child."

It is very ironic to note that, if we see the whole narratives from a scientific lens this is nothing but a simple physiological process of menstruation. The typical traditional belief of associating the whole process from monthly drying up of the flower inside the body on monthly basis and leading to the flow of menstrual blood can be directly related to the physiological process of menstruation. From the scientific perspective, during the time of menstruation is the discharge blood, a portion of tissue and blood are shed and replaced by new growth on a cyclic basis. Thus, it can be said that some cultural beliefs are very deeply rooted in our society, that simple physiological process is being reconstructed by our own social belief. The comparison made between the flower and menstruation in which the flower states that the young girl has just bloomed and menstruation symbolizes her fertility and sexuality. The fact comparing to the blooming of the flower states the period of monthly menstruation It symbolizes woman as a creator, power who can create life.

Nongbri observed a similar explanation where he mentioned about mother earth is compared to blossoming or ripening of flowers for bearing fruit. "The reproductive ideology and the gender role in Hindu tradition start with the metaphor of "seed" and "earth", which implies the subordination of women. The man is considered as the provider of the seed and the woman as the receiver, symbolically implying the womb as the earth for the nurture of the seed. Both the child and the field i.e., woman's womb is owned by man thus stating that the women have no control of her body" (Nongbri: 1988).

A Social Taboo: From the laymen's perspective, the term taboo denotes something which is forbidden. Sociocultural taboos are sanctioned by our social system, culture, and religion and of course we as a common people. The term "taboo" was introduced into the English language from the Polynesian word "tabu" by Captain James Cook. Taboo, i. e anything is forbidden was widely used by Sigmund Freud in his Totem and Taboo (1950) to define debarments such as "incest taboo". (Das, 2008).

When it comes to the menstrual taboo, there is a legend related to its origin in the Hindu Religion. The Vedic texts of India are full of mythological explanations on how women came to acquire the position of being impure and inferior to men in society, According to Hindu Religious myths, Indra, who is considered as one of the most eminent deities among all the Vedic God, who governs the whole universe especially the natural phenomena such as rains and season. The story narrative reveals that the king of heaven was accused of his sins, that is killing a brahmin (a high caste Hindu) and having illicit sexual acts with women during his quest. Therefore, to turn away from sin, all women were said to be punished through menstruation along with taboos. (Prakash, 2017). In the Vedic text Tarttiriyasamhita it was mentioned that when Indra killed Visvarupa, the son of Tvastr, he transferred one-third of the stain of murdering a Brahmin to women, the text relates that this took the form of women's menstrual period and concludes, therefore one should not converse with stained garments, nor should one with her or eat her food when she has emitted the colour of "Brahmahatya" (Leslie, 1991).

Menstrual taboos have been prevalent in our society since Vedic age, even though we are living in the twenty-first century it still exists and to a certain extent, it defines the existence of woman in some society. The whole "culture of menstruation" is ascribed through the sociocultural process of traditional rituals and belief systems, societal norms, gender-based roles, etc. Social taboos are deeply culturally rooted in komolsapori area, and they play a crucial role especially in women's way of life. Komolsapori area, like another village of Assam, has also its definite judgment about "menstrual culture". The status of menstruating women is considered as "impure" because people reside in this area irrespective of their cast, they strongly believe that “dirty' blood came out of the vagina.

Keeping Infront the purity, she is being secluded for the three days on a mandatory basis. Menstruating women are allowed to take rest for these mandatory days and don't come in contact with anyone to maintain the purity 
of their respective households. But the state of pollutant being stays with her for a weeklong of seven days. An Assamese woman (47) narrated her own experience, how social taboos and rules and restriction were laid down upon her whenever she had menstruation and how she is being treated by society, "I was kept secluded for mandatory three days in a separate closed room where no one is allowed to visit except a few elder female's family members. Only after a ritual bath after three days I am allowed to step out from my confined room $n$ do normal activities. Entering the prayer house is strictly prohibited for seven days. I am not allowed to touch any tangible or intangible items in the household as it is considered impure."

A Curse: Socio-Cultural Perception Towards Menstruation: Though women are being placed in a subordinate position in a male-dominated society, women are the only creator of life in the human race. In a country like India, where the menstruation of Mother Kamakhya is worshipped while at the same time, menstruating women are completely forced to seclusion during this time to counter their polluted state. It is indeed ironic to see, how on the one hand the menstrual cloth of kamakhya and fluid is being distributed as Prasad among the bhaktas on the other hand, in social scenario women with menstruation are considered as a threat to sacredness. On one hand, this natural process of menstruation that is a part of a woman's life is a symbol of blessing and on the other hand, it is considered impure. Menstruation as a blessing brings in the fact of woman as a power to produce a new life. While as a curse, a menstruating woman is considered impure and is forbidden during her periodical cycle.

Therefore, a question arises that how can menstruation be both a blessing and a curse at the same time? "Ma kamakhya is worshipped for her power to provide fertility, during the time of menstruation this power is believed to be heightened, hence more sensitive, thus resulting in her seclusion from any profane distraction. In the context of Assam, the power of the menstruating Goddess Kamakhya is considered as something that is immensely potent. Menstrual taboo imposed on the woman primarily rests on the idea of her profanes, whereas the menstrual taboo of Goddess Kamakhya essentially represents her sacredness, involving restriction not on the Goddess but $\mathrm{n}$ her believers. The fluidities and contradictions of social constructions around menstrual taboo become evident here. (Patar, 2019). Women of komolsapori area have big faith in Ma Kamakhya Sapna Das(57), who is a very staunch believer of Ma Kamakhya shared her story, she narrated,

"Every year during Jun July mother kamakhya Menstruates, we call it as "xaat loga", "suwa" in local terminology. Every work-related to mother nature or earth is strictly prohibited. I try to remain in bed as long as possible. Only boil food is being cooked in the kitchen and it is strongly believed nothing from the womb of nature should be used and people who reside in rural should not use any firewood for making food as firewood is a necessary part of nature. Any activity which is directly or indirectly related to nature should be avoided' In a country like India, where the first menstruation of a girl(menarche), is not a private affair at all rather it is being celebrated publicly.

Most of my participants positioned menstrual celebration as a public recognition of their entry into womanhood which should be socially recognized and accepted. Apart from that, from my observation, most of the women had less knowledge about the physiological process of menstruation rather they are being told to kept silent during the time of the month. Basic knowledge was also not provided by elders but rather young girls are being told to maintain "menstrual culture". some participant repeatedly shared their experiences that they are being told to maintain "distance", "avoid touching any tangible and intangible things", "be more careful in every step you make" during the time of menstruation from elderly women.

Status of Pollution: It is being believed that "bad blood" that contains germ is discharged from the body in a form of menstruation which in social structure symbolizes as "polluting state" of women. The status of pollution linked up with menstruation found in Komolsapori area too. Purity, pollution, and restrictions (taboos) have been written about by different authors for different societies. For example, Eichinger Ferro-Luzzi states that any members of society may be polluted at any given point of time where the pollution may be temporary or permanent, voluntary or involuntary, etc. women are generally polluted during their menstrual period as well as during delivery. These kinds of pollutions are involuntary and temporary wherein women become untouchable and may become unusable by men(1974). The need for practicing such restrictions as mentioned by the author is aptly taken forward by Doughlas(1966( where she suggests that societies give conformity to such rites and practices which are there to minimize the dangers people might encounter by associating pollution to their moral values. (Das, 2008).

\footnotetext{
"Some personal narratives were shared by a Nepali woman during my field visit where she said: "During the time of this month (period of menstruation) we become as polluted beings because we release polluted blood. Through Menstruation the polluted blood that forms inside a female body is let out from the vagina. we release the pollution from our body during menstruation so we are restricted to touch anything and follow seclusion for a certain period. All pure sacred places that are considered clean and pure such as the kitchen, the place of worship at home are meant to be avoided while menstruating because if consciously or unconsciously we touch any tangible and intangible items of this place it will automatically become impure. The kitchen is believed to be Goddess Lakhi's abode and the prayer house is considered as the house of different deities".
} 


\section{CONCLUSION}

The current research demonstrates that the simple biological element in women's bodies has been reconstructed by our society without proper scientific validation. Young girls and women are bound to follow it to fit in the social framework. In komolsapori area, women are still today abiding by the prevalent prescribed rules of society, and they considered their "state of menstruation" as a polluted one. Women considered themselves impure during the time of menstruation as they strongly agree and believed that the blood that came out from the vagina is polluted, which is unclean. If we trace the history of Indra's curse, to repent his sin women are punished in form of menstruation along with taboo, but they do not consider themselves as a cursed being either. The culture of menstruation will remain to exist in komolsapori area whether, in form of traditional beliefs, rituals, taboos, impurity, etc, there is less future possibility to eradicate from society itself.

During the entire fieldwork, women were quite vocal in their thoughts but men have always kept a distance during the discussion on menstruation. This study finding highlights that there is a complete absence of knowledge about the physiological process related to menstruation but rather their mind is fully occupied by socio-cultural dogmas. They have a positive approach and they were likely to consider menstruation as the only way to attain a child. Lastly to conclude this paper the process of socialization of young girls becomes an important concern specially for mothers. Moreover, while stating about the existing culture of menstruation, it depicts the harsh social reality in many forms, there is a need to know up to what extent this menstrual culture is being practiced in a different part of the globe.

Does enough literature present the existing menstrual culture? Lastly, “menstruation' is a basic normal physiological process that every girl goes through till menopause occurs but our society has reconstructed and reshaped with its ideologies and able to create and maintain existing social construction around “menstruation'. It's high time for us as a member of civil society to look into our very own perception towards existing social beliefs system, social norms regarding menstruation, practices, etc whether they are justified or not in the twenty-first century for young girls and women. We have the power to change this whole belief system if we change our attitude towards it and spontaneously that will also help our next generation to create an egalitarian society for women.

\section{REFERENCES}

Baldy, R C ( 2016). Mini-k'iwhe:n ( For That Purpose -I Consider Things0 : ( $\mathrm{Re}$ ) writing and (Re) righting Indigenous Menstrual Practices to Intervene on contemporary Menstrual Discourse and Politics of taboo. Cultural studies critical methodologies. 1(9),1-9.

Das, M. (2008). Menstruation as Pollution: Taboos in Simlitola. Indian Anthropological Association, 38 (2),29-42.

Hawkey J A, Ussher M J, Perz J, Metusela C (2016). Experience and Construction of Menarche and Menstruation Among Migrant and Refugee Women. Sage publication.1-18.

Hoskins J. (2002). Blood Mysteries: beyond Menstruation as pollution. Ethology 41(4), 299-301.

Kumari S,(2017). Social, Cultural and Religious Practices during Menstruation. Jharkhand Journal of development and Management Studies XISS, Ranchi, 15(3),7451-7459.

Mangar R. (2019). Bel Bibaha Among the Newars and its Social Significance. Social trends,journal of department of sociology of north Bengal university.6220-229.

Patar, M. (2019). Tuloni; Experience and Negotiations around Womanhood in Assamese Society. Exploration, 3(1), 65-88.

Rege, S. (ed.) (2003). Sociology of Gender, Gender and the Khasi Family Structure: The Meghalaya Succession to Self-Acuired Property Act, 1984. New Delhi: Sage Publications, pg.182-193.

Selvi T K, Ramachandran S,(2012). Socio-cultural taboos concerning Menstruation : A Micro Level study in the Cuddalore District of Tamil Nadu,India. international journal of scientific and research publication, 2(8).

Spanier, G B (1978). Sex education and premarital sexual behaviour among American college students. Adolescence, 13(52), 659-674.

Sridhar N. (2019). The Sabrimala Confusion Menstruation Across Culture A Historical Perspective. Vitasta Publishing Pvt Ltd.

Thomas M. E. (2007). Menstruation Discrimination; The Menstrual Taboo as a Rhetorical function of Discourse in the National and international advances of women's rights. Contemporary Argumentation and Debate, 28, 65-90.

Upadhya P. (2017). Menstruation and Pollution Taboos and Gender Based Violence in Western Nepal. The Nehu Journal, 15(2), 101-111. 